
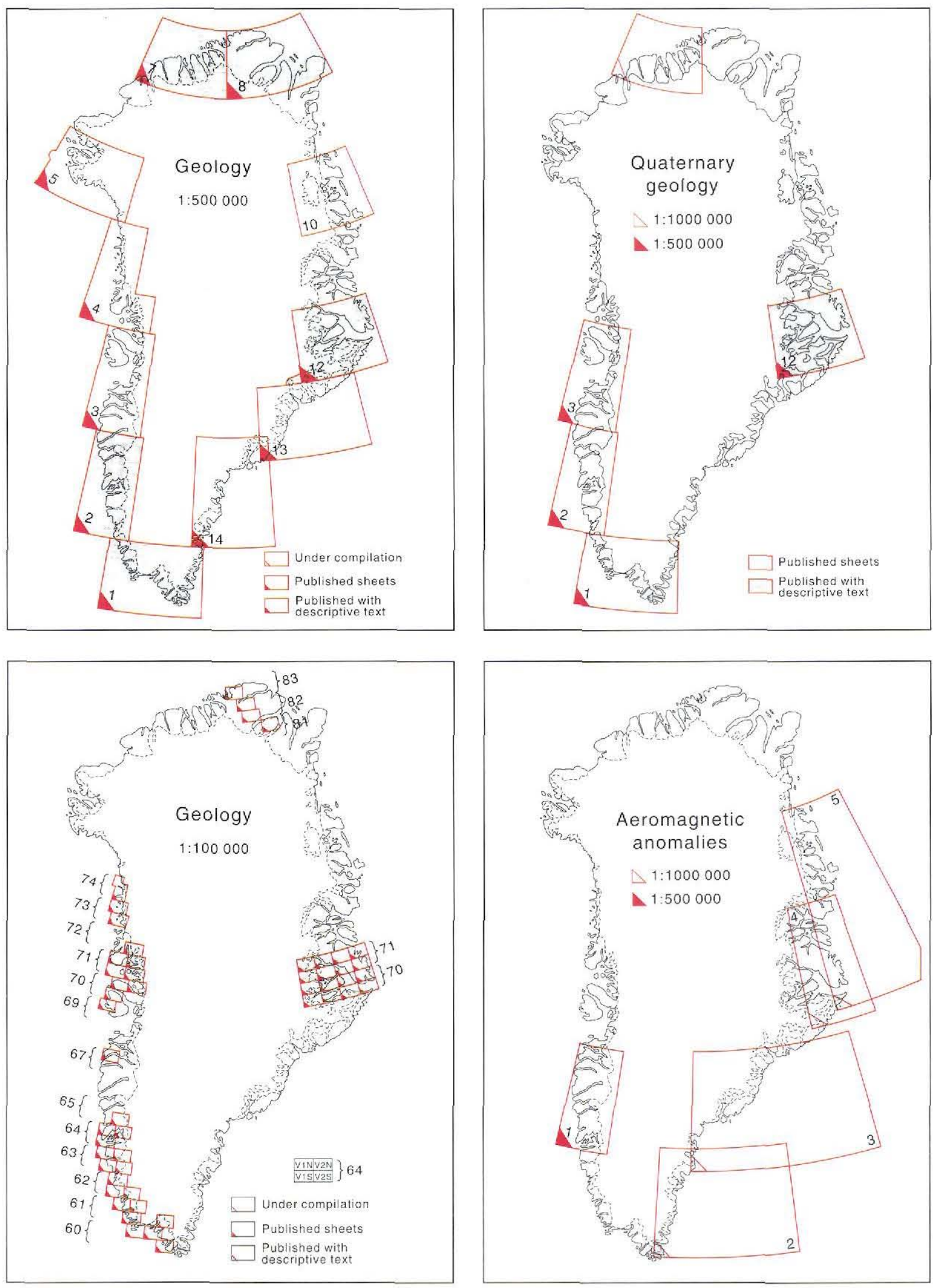

Map sheets published and in preparation by the Survey. 


\section{Publications of the Geological Survey of Greenland 1993}

\section{Map sheet descriptions}

64 V.1 S Qôrqut. Geological map of Greenland 1:100 000. Descriptive text. The regional geology of part of the Archaean block of southern West Greenland, including a segment of the late Archaean mobile belt through Godthåbsfjord. 1993 by V. R. McGregor. 40 pp.

\section{Bulletins (Bull. Gronlands geol. Unders.)}

164 Acritarchs from the Lower Cambrian Buen Formation in North Greenland. 1993 by G. Vidal \& J. S. Peel, 35 pp.

165 Lithostratigraphy of the continental Devonian sediments in North-East Greenland. 1993 by H. Olsen \& P.-H. Larsen, 110 pp.

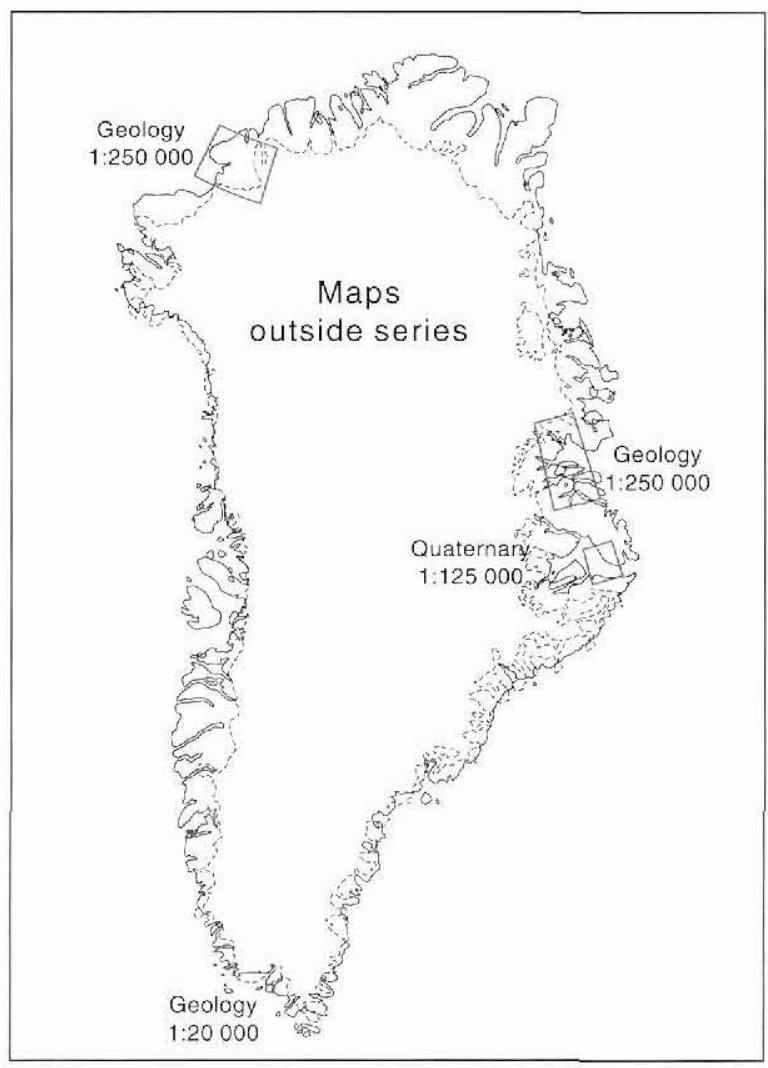

166 Dinoflagellate cyst stratigraphy of the Barremian to Albian, Lower Cretaccous, North-East Greenland. 1993 by H. Nøhr-Hansen, 171 pp.

167 Lithostratigraphic framework of the Upper Proterozoic Eleonore Bay Supergroup of East and North-East Greenland. 1993 by M. Sønderholm \& H. Tirsgaard, $38 \mathrm{pp}$.

168 Sedimentary basin analysis of the continental Devonian basin in North-East Greenland. 1993 by H. Olsen, $80 \mathrm{pp}$.

\section{Reports (Rapp. Gronlands geol. Unders.)}

159 Grønlands Geologiske Underøgelse 1993: Current research including Report of activities, 1992. 1993 edited by A. K. Higgins \& M. Sønderholm, 126 pp.

\section{Report of activities}

Articles in the annual Report of activities of the Survey published as Rapp. Gronlands geol. Unders. 159.

GGU's aktiviteter i 1992. 1993 by M. Ghisler, 6-7.

Review of the Survey's activities in 1992. 1993 by M. Ghisler, 8-9.

An overview of Greenland's mineral exploration potential. 1993 by H. K. Schønwandt \& P. R. Dawes, 10-16.

Greenland MINEX News: a new service for the mining industry. 1993 by P. R. Dawes \& H. H. Thomsen, 16-18.

Greenland mineral resource information to industry: increased scope in 1992.1993 by P. R. Dawes, H. K. Schønwandt \& B. Thomassen, 18-21.

GGU Open File Series: a review of reports related to Greenland mineral exploration. 1993 by H. K. Schønwandt, 22-24.

Project SUPRASYD 1992: opening season in the Ketilidian of South Greenland. 1993 by T. F. D. Nielsen, B. Chadwick, P. R. Dawes, R. A. Frith \& H. K. Schønwandt. 25-31.

Geochemical mapping and geological reconnaissance in the Nagssugtogidian mobile belt, West Greenland. 1993 by A. Steenfelt, F. Kalsbeek \& H. F. Jepsen, 31-37. 
Petroleum-geological activities in 1992: preparation and support for licensing rounds offshore West Greenland. 1993 by F. G. Christiansen, C. Marcussen \& T. C. R. Pulvertaft, 38-42.

Ice conditions offshore West Greenland. 1993 by H. H. Thomsen, 43-47.

Disko Bugt Project 1992, West Greenland. 1993 by F. G. Christiansen, 47-52.

Sedimentological and stratigraphical analysis of the Upper Triassic - Lower Jurassic succession in Jameson Land, East Greenland - a summary. 1993 by G. Dam, 53-58

Evaluation of hydropower potential for possible future industrial use, Nuuk area, West Greenland. 1993 by H. H. Thomsen, R. J. Braithwaite, A. Weidick \& O. B. Olesen, 59-62.

Measurements of firn density in the lower accumulation area of the Greenland ice sheet: EPOCH 1992. 1993 by R. J. Braithwaite \& M. Laternser, 62-65.

Palaeo-environmental studies on the Greenland ice sheet margin. 1993 by N. Reeh, H. H. Thomsen \& C. E. Bøggild, 66-68.

Ocean Drilling Program (ODP) off South-East Greenland: formation of a volcanic rifted margin. 1993 by $\mathrm{H}$. C. Larsen, 69-73.

\section{Open File Series}

93/1 Reconnaissance geochemical mapping of map sheets 67 V.1 and 68 V.1 $\left(66^{\circ}\right.$ to $68^{\circ} \mathrm{N}, 51^{\circ} 40^{\prime}$ to $\left.54^{\circ} \mathrm{W}\right)$, West Greenland. 1993 by A. Steenfelt, E. Dam \& J. P. Nielsen, 16 pp.

93/2 Project AEROMAG-92: a new high resolution aeromagnetic survey of the Lersletten area, central West Greenland $\left(68^{\circ} 15^{\prime}\right.$ to $68^{\circ} 55^{\prime} \mathrm{N}, 50^{\circ} 25^{\prime}$ to $\left.53^{\circ} 35^{\prime} \mathrm{W}\right)$. 1993 by L. Thorning, 36 pp.

93/3 Gold exploration on the 'Nanortalik peninsula', South Greenland. 1993 by P. W. U. Appel, M. Lind \& J. P. Nielsen, $66 \mathrm{pp}$.

93/4 Stream sediment geochemical evidence for gold mineralisation in Hudson Land $\left(73^{\circ} 10^{\prime}\right.$ to $74^{\circ} 25^{\prime} \mathrm{N}$, $21^{\circ} 30^{\prime}$ to $24^{\circ} 45^{\prime} \mathrm{W}$ ), North-East Greenland. 1993 by A. Steenfelt, 25 pp.

93/5 Mass balance and related topics of the Greenland ice sheet. 1993 edited by N. Reeh \& H. Oerter, 92pp.

93/6 Gold and platinum-group element anomalies in the Fiskenæsset stratiform anorthosite complex, West Greenland. 1993 by P. W. U. Appel, 24 pp.

93/7 Update on the gold and base metal potential of the Íngia area, central West Greenland. 1993 by B. Thomassen, $66 \mathrm{pp}$.

93/8 Project to assess the application of Spot and Landsat TM imageries to geological reconnaissance, South-
East Greenland. Final report. 1993 by T. Tukiainen, P. Erfurt \& L. Thorning, 32pp.

\section{Geological profiles}

Geological section along the south coast of Nuussuaq, central West Greenland. 1:20 000. Coloured geological sheet. 1993 by A. K. Pedersen, L. M. Larsen \& K. S. Dueholm. Copenhagen: Geological Survey of Greenland.

\section{Scientific articles}

Refereed works published by GGU or externally. Articles written by non-GGU staff but arising from work partly funded by GGU or from co-operative projects are also included.

Bailey, J. C., Bohse, H., Gwozdz, R. \& Rose-Hansen, J. 1993: Li in minerals from the Ilímaussaq alkaline intrusion, South Greenland. Bull. geol. Soc. Denm. 40, 288299.

Bennett, V. C., Nutman, A. P. \& McCulloch, M. T. 1993: Nd isotopic evidence for transient, highly depleted mantle reservoirs in the early history of the Earth. Earth planet. Sci. Lett. 119, 299-317.

Braithwaite, R. J. 1993: Firn temperature and meltwater refreezing in the lower accumulation area of the Greenland ice sheet, Pâkitsoq, West Greenland. Rapp. Grønlands geol. Unders. 159, 109-114.

Braithwaite, R. J. 1993: Is the Greenland ice sheet getting thicker? Climatic Change 23, 379-381.

Braithwaite, R. J. \& Olesen, O. B. 1993: Seasonal variation of ice ablation at the margin of the Greenland ice sheet and its sensitivity to climatic change, Qamanârssûp sermia, West Greenland. J. Glaciol. 39, 267-274.

Chalmers, J. A. \& Pulvertaft, T. C. R. 1993: The southern Greenland continental shelf - was petroleum exploration abandoned prematurely? In Vorren, T. O., Bergsager, E., Dahl-Stamnes, Ø. A., Holter, E., Johansen, B., Lie, E. \& Lund, T. B. (ed.) Arctic geology and petroleum potential. Norweg. Petrol. Soc. Spec. Publ. 2, 55-66.

Chadwick, B., Friend, C. R. L., George, M. C. \& Perkins, W. T. 1993: A new occurrence of musgravite, a rare beryllium oxide, in the Caledonides of North-East Greenland. Mineralog. Mag. 57, 121-129.

Chalmers, J. A., Pulvertaft, T. C. R., Christiansen, F. G., Larsen, H. C., Laursen. K. H. \& Ottesen, T. G. 1993: The southern West Greenland continental margin: rifting history, basin development, and petroleum potential. In Parker, J. R. (ed.) Petroleum geology of Northwest Europe: Proceedings of the 4th Conference, 915-931. London: The Geological Society.

Christiansen, F. G., Piasecki, S., Stemmerik, L. \& Telnæs, 
N. 1993: Depositional environment and organic geochemistry of the Upper Permian Ravnefjeld Formation source rock in East Greenland. Bull. Amer. Assoc. Petrol. Geol. 77, 1519-1537.

Christiansen, F. G., Larsen, H. C., Marcussen, C., Piasecki, S. \& Stemmerik, L. 1993: Late Paleozoic plays in East Greenland. In Parker, J. R. (ed.) Petroleum geology of Northwest Europe: Proceedings of the 4th Conference, 657-666, London: Geological Society.

Clemmensen, L. B. \& Dam, G. 1993: Aeolian sand-sheet deposits in the Lower Cambrian Neks $\varnothing$ Sandstone Formation, Bornholm, Denmark: sedimentary architecture and genesis. Sediment. Geol. 83, 71-85.

Dam, G. \& Surlyk, F. 1993: Cyclic sedimentation in a large wave and storm-dominated anoxic lake: Kap Stewart Formation (Rhaetian-Sinemurian), Jameson Land, East Greenland. In Posamentier, H. W., Summerhayes, C. P., Haq, B. U. \& Allen, G. P. (ed.) Sequence stratigraphy and facies associations. Spec. Publs int. Ass. Sediment. 18, 419-448.

Dueholm, K. S. \& Olsen, T. 1993: Reservoir analog studies using multimodel photogrammetry: a new tool for the petroleum industry. Bull. Amer. Ass. Petrol. Geol. 77, 20232031.

Dueholm, K. S., Garde, A. A. \& Pedersen, A. K. 1993: Preparation of accurate geological and structural maps, crosssections or block diagrams from colour slides, using multi-model photogrammetry. J. struct. Geol. 15, 933937.

Gilotti, J. 1993: Discovery of a medium-temperature eclogite province in the Caledonides of North-East Greenland. Geology 21, 523-526.

Holm, P. M., Gill, R. C. O., Pedersen, A. K., Larsen, J. G., Hald, N., Nielsen, T. F. D. \& Thirlwall, M. F. 1993: The Tertiary picrites of West Greenland: contributions from 'Icelandic' and other sources. Earth planet. Sci. Lett. 115, 227-244.

Jensen, S. M. 1993: Lead isotope studies on mineral showings and ore deposits in East Greenland. Rapp. Grønlands geol. Unders. 159, 101-108.

Jensen, S. M. 1993: Lead isotope composition of stratabound $\mathrm{Cu}-\mathrm{Pb}-\mathrm{Zn}$-Ba occurrences in Upper Palaeozoic Mesozoic sediments in East Greenland. In Fenoll HachAlí, P., Torres-Ruiz, J. \& Gervilla, F. (ed.) Current research in geology applied to ore deposits, 327-330. Granada: Universidad de Granada.

Kalsbeek, F. 1993: Use of Rb-Sr isotope data to constrain the time of deposition of Precambrian metasediments: an example from Hamborgerland, West Greenland. Rapp. Grønlands geol. Unders. 159, 95-100.

Kalsbeek, F. \& Taylor, P. N. 1993: Sm-Nd isotope age data from the Archaean Skjoldungen area, South-East Greenland. Rapp. Grønlands geol. Unders. 159, 89-93.
Kalsbeek, F., Austrheim, H., Bridgwater, D., Hansen, B. T., Pedersen, S. \& Taylor, P. N. 1993: Geochronology of Archaean and Proterozoic events in the Ammassalik area, South-East Greenland, and comparisons with the Lewisian of Scotland and the Nagssugtoqidian of West Greenland. Precambrian Res. 62, 239-270.

Kalsbeek, F., Nutman, A. P. \& Taylor, P. N. 1993: Palaeoproterozoic basement province in the Caledonian fold belt of North-East Greenland. Precambrian Res. 63, 163-178.

Kelly, S. B. \& Olsen, H. 1993: Terminal fans - a review with reference to Devonian examples. Sedim. Geol. 85, 339374.

Koch, C. B. \& Christiansen, F. G. 1993: Maturation of Lower Palaeozoic kerogens from North Greenland. Org. Geochem. 20, 405-413.

Koppelhus, E. B. \& Pedersen, G. K. 1993: A palynological and sedimentological study of Cretaceous floodplain deposits of the Atane Formation at Skansen and Igdlunguaq, Disko, West Greenland. Cretaceous Res. 14, 707-734.

Larsen, L. M. \& Rønsbo, J. 1993: Conditions of origin of kimberlites in West Greenland: new evidence from the Sarfartoq and Sukkertoppen regions. Rapp. Grønlands geol. Unders. 159, 115-120.

Myers, J. S., Gill, R. C. O., Rex, D. C. \& Charnley, N. R. 1993: The Kap Gustav Holm Tertiary plutonic centre, East Greenland. J. geol. Soc., Lond. 150, 259-276.

Nilsen, T. [Nielsen, T. F. D.] 1993: [Swarms of alkaline dikes of the Gardiner complex and formation of ultrabasite-alkaline complexes.] Geokhimiya 1993, 11121131. (In Russian).

Nielsen, T. F. D. \& Holm, P. M. 1993: Nd and Sr isotope compositions from the Gardiner Complex, East Greenland Tertiary igneous province. Bull. geol. Soc. Denm. 40, 280-287.

Nøhr-Hansen, H. 1993: Dinoflagellate cyst stratigraphy of the Barremian to Albian, Lower Cretaceous, NorthEast Greenland. Bull. Grønlands geol. Unders. 166, 171 pp.

Nøhr-Hansen, H. 1993: Upper Maastrichtian? - lower Paleocene dinoflagellate cysts and pollen from turbidites in the Itilli region, Nuussuaq, central West Greenland first dating of the sediments. Rapp. Gronlands geol. Unders. 159, 81-87.

Nutman, A. P., Friend, C. R. L., Kinny, P. D. \& McGregor, V. R. 1993: Anatomy of an Early Archean gneiss complex: 3900 to $3600 \mathrm{Ma}$ crustal evolution in southern West Greenland. Geology 21, 415-518.

Olsen, H. 1993: Sedimentary basin analysis of the continental Devonian basin in North-East Greenland. Bull. Grønlands geol. Unders. 168, 80 pp.

Olsen, H. \& Larsen, P.-H. 1993: Lithostratigraphy of the continental Devonian sediments in North-East Greenland. Bull. Grønlands geol. Unders. 165, 110 pp. 
Olsen, H. \& Larsen, P.-H. 1993: Structural and climatic controls on fluvial depositional systems - Devonian, North-East Greenland. In Marzo, M. \& Puigdefabregas, C. (ed.) Alluvial sedimentation. Spec. Publs int. Ass. Sediment. 17, 401-423.

Olsen, T. 1993: Large fluvial systems: the Atane Formation, a fluvio-deltaic example from the Upper Cretaceous of central West Greenland. Sediment. Geol. 85, 457-473.

Reeh, N. \& Thomsen, H. H. 1993: Using stable isotopes as natural tracers to delineate hydrological drainage basins on the Greenland ice-sheet margin. Chem. Geol. (Isotope Geosci. Sect.) 109, 281-291.

Robinson, D., Bevins, R. E. \& Rowbotham, G. 1993: The characterization of mafic phyllosilicates in low-grade metabasalts from eastern North Greenland. Amer. Miner. 78, 377-390.

Scholle, P. A., Stemmerik, L., Ulmer-Scholle, D., Di Liegro, G. \& Henk, F. H. 1993: Palaeokarst-influenced depositional and diagentic patterns in Upper Permian carbonates and evaporites, Karstryggen area, central East Greenland. Sedimentology 40, 895-918.

Sønderholm, M. \& Tirsgaard, H. 1993: Lithostratigraphic framework of the Upper Proterozoic Eleonore Bay Supergroup of East and North-East Greenland. Bull. Grønlands geol. Unders. 167, 38 pp.

Soper, N. J. \& Higgins, A. K. 1993: Basement-cover relationships in the East Greenland Caledonides: evidence from the Eleonore Bay Supergroup at Ardencaple Fjord. Trans. roy. Soc. Edinb., Earth Sci. 84, 103-115.

Steenfelt, A. 1993: Geochemical mapping-progress in Greenland. J. geochem. Explor. 49, 5-13.

Steenfelt, A. 1993: Comparisons of geochemical patterns obtained from stream sediment, stream organics and till in the Nordkalott project in Fennoscandia. J. geochem. Explor: 49, 145-159.

Steiger, R. H., Bickel, R. A. \& Meier, M. 1993: Conventional $\mathrm{U}-\mathrm{Pb}$ dating of single fragments of zircon for petrogenetic studies of Phanerozoic granitoids. Earth planet. Sci. Lett. 115, 197-209.

Stemmerik, L. 1993: Moscovian bryozoan-dominated build-ups, northern Amdrup Land, eastern North Greenland. In Vorren, T. O., Bergsager, E., Dahl-Stamnes, Ø. A., Holter, E., Johansen, B., Lie,E. \& Lund, T. B. (ed.) Arctic geology and petroleum potential. Norweg. Petrol. Soc. Spec. Publ. 2, 99-106.

Stemmerik, L. \& Larssen, G. B. 1993: Diagenesis and porosity evolution of Lower Permian Palaeoaplysina build-ups, Bjørnøya: an example of diagenetic response to high frequency sea level fluctuations in an arid cli- mate. In Horbury, A. D. \& Robinson, A. G. (ed.) Diagenesis and basin development. Amer. Ass. Petrol. Geol., Studies in Geol. 36, 199-211.

Stemmerik, L., Christiansen, F. G., Piasecki, S., Jordt, B., Marcussen, C. \& Nøhr-Hansen, H. 1993: Depositional history and petroleum geology of the Carboniferous to Cretaceous sediments in the northern part of East Greenland. In Vorren, T. O., Bergsager, E., Dahl-Stamnes, $\emptyset$. A., Holter, E., Johansen, B., Lie, E. \& Lund, T. B. (ed.) Arctic geology and petroleum potential. Norweg. Petrol. Soc. Spec. Publ. 2, 67-87.

Stemmerik, L., Scholle, P. A., Henk, F. H., DiLiegro, G. \& Ulmer, D. S. 1993: Sedimentology and diagenesis of the Upper Permian Wegener Halvø Formation carbonates along the margins of the Jameson Land Basin, East Greenland. In Vorren, T. O., Bergsager, E., Dahl-Stamnes, Ø. A., Holter, E., Johansen, B., Lie, E. \& Lund, T. B. (ed.) Arctic geology and petroleum potential. Norweg. Petrol. Soc. Spec. Publ. 2, 107-119.

Surlyk, F., Noe-Nygaard, N. \& Dam, G. 1993: High and low resolution sequence stratigraphy in lithological prediction - examples from the Mesozoic around the northern North Atlantic. In Parker, J. R. (ed.) Petroleum geology of Northwest Europe: Proceedings of the 4th Conference, 199-214. London: The Geological Society.

Taylor, P. N. \& Upton, B. G. J. 1993: Contrasting Pb isotopic compositions in two intrusive complexes of the Gardar Magmatic Province of South Greenland. Chem. Geol. (Isotope Geosci. Sect.) 104, 261-268.

Thomsen, T. \& Weidick, A. 1993: Climate change impacts on northern water resources in Greenland. In Prowse, T. D., Ommanney, C. S. L. \& Ulmer, K. (ed.) Proceedings Ninth International Northern Research Basins. Nat. Hydrol. Res. Inst. Symp. 10(2), 749-781.

Tirsgaard, H. 1993: The architecture of Precambrian high energy tidal channel deposits: an example from the Lyell Land Group (Eleonore Bay Supergroup), northeast Greenland. Sedim. Geol. 88, 137-152.

Tucker, R. D., Dallmeyer, R. D. \& Strachan, R. A. 1993: Age and tectonothermal record of Laurentian basement, Caledonides of NE Greenland. J. geol. Soc., Lond. 150, 371-379.

Vidal, G. \& Peel, J. S. 1993: Acritarchs from the Lower Cambrian Buen Formation in North Greenland. Bull. Gronlands geol. Unders. 164, 35 pp.

Weidick, A. 1993: Neoglacial change of ice cover and the related response of the Earth's crust in West Greenland. Rapp. Grønlands geol. Unders. 159, 121-126. 